УДК 618.179:57.04

DOI 10.11603/24116-4944.2020.2.11858

\author{
${ }^{\circ}$ С. В. Хміль ${ }^{1,2}$ О. В. Денефіль ${ }^{2}$ Н. Ю. Терлецька², О. Ю. Майорова ${ }^{1,3}$ \\ ${ }^{1}$ Медичний центр «Клініка професора С. Хліля» \\ ${ }^{2}$ Тернопільсъкий національний медичний університет \\ ілені I. Я. Горбачевсъкого МОЗ України \\ ${ }^{3}$ Тернопільсъкий національний педагогічний університет імені Володимира Гнатюка

\section{НИЗЬКИЙ ОВУЛЯТОРНИЙ РЕЗЕРВ: ПРИЧИНИ ВИНИКНЕННЯ, ПИТАННЯ ТА ВІДПОВІДІ}

\begin{abstract}
Мета дослідження - вивчення та аналіз факторів, які негативно впливають на репродуктивну функцію яєчників.
Матеріали та методи. У роботі використано загальнонаукові методи дослідження: аналіз і синтез, індукцію та дедукцію, аналогію, абстрагування і конкретизацію, системний аналіз, формалізацію.

Результати дослідження та їх обговорення. Під час виконання дослідження було проаналізовано 43 джерела сучасної вітчизняної та зарубіжної літератури щодо причин погіршення репродуктивної фрункції яєчників.

Висновки. Аналіз літературних джерел показав, що на стан яєчників та оваріальний резерв негативно впливають різні фрактори: анамнез (генетична схильність, ускладнений пренатальний період, операції на яєчниках, ендометріоз, інфекції органів таза, соматична патологія), вік, стиль життя (індекс маси тіла, вживання алкоголю та кави, куріння), шкідливі фрактори навколишнього середовища (атмосферозабруднюючі речовини, пестициди, радіоактивні агенти).
\end{abstract}

Ключові слова: оваріальний резерв; фрертильність жінки; анамнез; спосіб життя.

НИЗКИЙ ОВУЛЯТОРНЫЙ РЕЗЕРВ: ПРИЧИНЫ ВОЗНИКНОВЕНИЯ, ВОПРОСЫ И ОТВЕТЫ

Цель исследования - изучение и анализ фракторов, которые негативно влияют на репродуктивную фрункцию яичников.

Материалы и методы. В работе использованы общенаучные методы исследования: анализ и синтез, индукция и дедукция, аналогия, абстрагирование и конкретизация, системный анализ, срормализация.

Результаты исследования и их обсуждение. Во время выполнения исследования было проанализировано 43 источника современной отечественной и зарубежной литературы о причинах ухудшения репродуктивной фрункции яичников.

Выводы. Анализ литературных источников показал, что на состояние яичников и овариальный резерв негативно влияют различные фракторы: анамнез (генетическая предрасположенность, осложненный пренатальный период, операции на яичниках, эндометриоз, иноекции органов таза, соматическая патология), возраст, стиль жизни (индекс массы тела, употребление алкоголя и кофе, курение), вредные фракторы окружающей среды (вещества, загрязняющие атмоссеру, пестициды, радиоактивные агенты).

Ключевые слова: овариальный резерв; фертильность женщины; анамнез; образ жизни.

LOW OVULATORY RESERVE: CAUSES, QUESTIONS AND ANSWERS

The aim of the study - to learn and analyze the factors that negatively affect the reproductive function of the ovaries.

Materials and Methods. General scientific research methods were used in the research: analysis and synthesis, induction and deduction, analogy, abstraction and concretization, system analysis, formalization.

Results and Discussion. During the study, 43 sources of modern domestic and foreign literature on the causes of deterioration of ovarian reproductive function were analyzed.

Conclusions. Analysis of literature sources showed that the condition of the ovaries and ovarian reserve are negatively affected by various factors: anamnesis (genetic predisposition, complicated prenatal period, ovarian surgery, endometriosis, pelvic infections, somatic pathology), age, lifestyle (body mass index, alcohol and coffee consumption, smoking), harmful environmental factors (air pollutants, pesticides, radioactive agents).

Key words: ovarian reserve; female fertility; anamnesis; way of life.

ВстУп. Науково-технічний процес, який є визначальним пусковим механізмом орормування сучасного світу, привів, з одного боку, до розвитку наукового і технологічного потенціалу, зростання промисловості, збільшення чисельності населення та росту урбанізації, хімізації сільського господарства, які, з іншого боку, неминуче призводять до збільшення експлуатації природних ресурсів, роблять усе глибшим вплив на навколишню природу. 3 іншого боку, досягнення та успіхи в розвитку науки, гігієнічної зокрема, медицини, заходів з охорони i відтворення навколишнього середовища, дають можливість вжити заходів для запобігання негативним впливам виробництва на середовище, яке оточує людину.
Однак, незважаючи на усі використовувані заходи покращення умов існування, пресинг негативних фракторів середовища на організм людини щорічно зростає. I найбільш чутливою $€$ репродуктивна система. Основне навантаження з проблем репродуктивного здоров'я припадає на жінок, їх репродуктивний ризик проявляється на сімейному та популяційному рівнях і об'єднує всі соціальні та медичні фрактори, що призводять до зниження народжуваності й погіршення здоров'я нового покоління [1]. На сьогодні в Україні ця проблема гостро постає через від'ємний приріст населення та збільшення числа безплідних сімей.

МЕТА ДОСЛІДЖЕННЯ - вивчення та аналіз фракторів, які негативно впливають на репродуктивну функцію яєчників. 
МАТЕРІАЛИ ТА МЕТОДИ. БУЛо використано загальнонаукові методи дослідження. Вони включають аналіз і синтез, індукцію та дедукцію, аналогію, абстрагування і конкретизацію, системний аналіз, формалізацію.

РЕЗУЛЬТАТИ ДОСЛІДЖЕННЯ ТА ЇХ ОБГОВОРЕННЯ. У жінок первинні фролікули фрормуються під час ембріонального розвитку, тому створення резерву яєчників перебуває під контролем материнського організму. Усі зміни (метаболічні, гормональні, зміни здоров'я) у материнському організмі, а також забруднювачі, які здатні проникати через плаценту, можуть впливати на розвиток статевих залоз плода. Ці материнські чинники або фрактори зовнішнього середовища можуть впливати на розвиток яєчників як безпосередньо, так і опосередковано, зокрема через порушення гіпоталамо-гіпофрізарного комплексу, фрункцій печінки та підшлункової залози [2].

На репродуктивну функцію яєчників негативно впливають різні фактори: генетична схильність, ускладнений пренатальний період, операції на яєчниках, ендометріоз, інсрекції органів таза в анамнезі, соматична патологія, хіміотерапія, вік, стиль життя (індекс маси тіла, вживання алкоголю та кави, куріння, стрес), шкідливі фрактори навколишнього середовища (атмоссрерозабруднюючі речовини, пестициди, радіоактивні агенти) [3, 4].

Значно знижують репродуктивний потенціал жінки хронічні запальні захворювання органів малого таза, причому, крім звичайного у цій ситуації трубно-перитонеального фрактора безплідності, фрормуються також порушення кровотоку яєчників, автоімунні пошкодження тканин, порушення гормонорецепції у тканинах яєчників [5-7].

Хірургічні втручання. Частота хірургічних втручань у репродуктивному періоді на органах малого таза становить 7-26 \% стосовно усіх операцій [8]. Хірургічні втручання на яєчниках та матці не можуть не впливати на їхній функціональний стан. Виконання оперативного втручання у щадному обсязі з максимальним збереженням здорової тканини дозволяє зберегти овуляторний резерв і репродуктивне здоров'я жінки [9].

Чим більше оперативних втручань на матці, яєчниках та/або чим вища їхня травматичність, тим сильніше страждає запас яйцеклітин, здатних до запліднення. Потенційно низький оваріальний резерв $€$ не тільки причиною жіночого безпліддя, але і частих невдач екстракорпорального запліднення $[8,10]$.

Вплив кесаревого розтину на репродуктивну функцію яєчників. Єгипетські дослідники Rahma Abdelwahab Ibrahim та Amal Abdelaziz Nouh (акушерсько-гінекологічні відділення університетських лікарень Загазігу, Єгипет) провели дослідження щодо оцінки фрункції яєчників після кесаревого розтину. 48 пацієнтів було класиоріковано на дві групи (по 24 у кожній): 1 група - пацієнти, яким було проведено операцію кесаревого розтину (дослідна група); 2 група - пацієнти, яким відмінили кесарів розтин (контрольна група). Через три місяці після операції визначали рівень ФСГ, лГ, естрадіолу в сироватці крові, оцінювали індекс стійкості та індекс пульситильності артерії яєчників, кількість антральних фоолікулів обох яєчників. У результаті виявлено статистично значущу різницю між середнім значенням сироваткового ФСГ $(6,9 \pm 3,2)$ у дослідній групі порівняно з контролем $(4,8 \pm 2,4)$; статистично значущу різницю середнього значення ЛГ $(9,3 \pm 8,3-$ у дослідній групі; 3,2ะ1,9 -у контрольній групі); відсутність різниці у рівні естрадіолу в сироватці із збереженням припливу крові до обох яєчників через суттєві зміни індексу стійкості та індексу пульситильності артерії яєчника [11].

Вплив лапароскопічного втручання на оваріальний резерв. У гінекології оперативна лапароскопія найбільш часто застосовується для втручань на придатках матки, передусім, яєчниках. Для збереження оваріального резерву велике значення має метод гемостазу, який використовується під час операцій на яєчниках. Відповідно до даних світової літератури, методи гемостазу під час оперативних втручань на яєчниках істотно відрізняються: одні лікарі віддають перевагу використанню лігатурної та шовної техніки, інші - ендокліпсам, змішувальним апаратам; прихильники високих хірургічних енергій застосовують моно- та біполярну електрохірургію, рідше - когерентне випромінювання різних типів $[8,12]$.

За умови проведення лапароскопічного втручання біполярною коагуляцією потрібно враховувати, що під час коагуляції настає передчасне згасання фуннції яєчників, що зумовлено денатурацією білка (початкова стадія денатурації починається до $45^{\circ} \mathrm{C}$ ). Така ситуація призводить до зниження оваріального резерву в молодому віці пацієнток [13]. Отримані результати необхідно враховувати як під час оперативного лікування жінок репродуктивного віку, так і під час відновлення їх репродуктивної фрункції, у тому числі і з використанням допоміжних репродуктивних технологій [14]

Втім, дослідник Enas M. Yaseen провів ряд обстежень жінок до і після оперативних втручань (лапаротомія та лапароскопія) і не виявив значного зменшення резерву яєчників після різних операцій на органах малого таза, за умови застосування мінімальної кількості електрокоагуляції під час операції [15].

Вік жінки є найбільш відомим фрактором, що сприяє зменшенню оваріального резерву і, мабуть, найважливішим прогностичним фрактором у лікуванні фрертильності жінок із низьким запасом ооцитів [16]. Життєздатність та якість яйцеклітин суттєво знижуються після 30-річного віку $[7,18,19]$, безпліддя значно зростає після 35 років. Matorras R. та ін. повідомляли, що у популяції жінок число народжених немовлят починає експоненціально зменшуватися у віковій категорії 35-39 (n=89 287) [20]. В історичних когортах рівень безпліддя серед жінок, які виходили заміж у вікових групах 20-24, 25-29, 30-34, 35-39 та 40-44 роки, становив 6, 9, 15, 30 та 64 \% відповідно [18]. У віці 45 років приблизно $99 \%$ жінок є безплідними.

Причинами зниження якості ооцитів, що призводить до аномального запліднення та невпорядкованої імплантації ембріонів, є вікова аномальна васкуляризація, оксидативний стрес, дисбаланс вільних радикалів, токсичні та генетичні зміни в організмі жінки [16]. Серед генетичних аномалій, які впливають на настання та виношування вагітності, можна виокремити еуплоїдію та анеуплоїдію. Встановлено, що еуплоїдія обернено корелює з віком жінки ( $<<0.01 ; n=544)$ [21]. В іншому дослідженні повідомлялося, що рівень анеуплоїдії у жінок, старших 35 років, становив 45,7 \% проти 34,8 \% у жінок до 35 років ( $n=352$, $\mathrm{p}=0,018)$ [22]. Хромосомні аномалії та анеуплоїдія можуть збільшувати ризик спонтанного аборту та порушення імплантації із збільшенням віку жінки [23, 24].

Харчування жінки також значною мірою впливає на іiї срертильність, особливо на овуляцію: 
- Chavarro J. Е. зі співавт. (2008а) підтверджено негативний вплив на овуляторну фертильність жінки заміни вуглеводів тваринним білком. Додавання лише однієї порції м'яса (особливо індичатини або курятини) корелювало зі збільшенням розвитку овуляторного безпліддя на 32 \%. Заміна вуглеводів рослинним білком викликала позитивний ефект [25];

- заміна мононенасичених жирів на трансжири у раціоні різко збільшує ризик овуляторного безпліддя [26] Споживання трансжирів замість вуглеводів корелювало із збільшенням ризику розвитку овуляторного розладу на $73 \%$ [26];

- Chavarro J. Е. та ін. (2008б) встановили, що жінки, у раціоні яких за співвідношенням більше мононенасичених, ніж трансжирів, білків рослинного походження порівняно з білками тваринного походження, молочних продуктів із високим вмістом жиру порівняно із знежиреними, які дотримуються дієти із зниженим глікемічним навантаженням, збільшенням споживання заліза та полівітамінів, мали меншу схильність до безпліддя через порушення овуляції [27];

- Lin K. зі співавт. (2010) підтвердили позитивну кореляцію між споживанням кави та зменшенням оваріального резерву (оваріальний резерв 2,48; 95 \% інорертильний контроль; $p=0,03)$ [28].

Харчування матері під час вагітності бере участь у програмуванні росту, розвитку і фрункціонуванні основних систем органів у плода. Саме тому плацентарна недостатність погіршує розвиток плода, зменшує кількість первинних фролікулів у яєчниках і, як наслідок, призводить до порушення репродуктивної функції нащадків [29].

Маса. Зайва маса у жінок, як і в чоловіків, є причиною порушення репродуктивної функції. Так, наприклад, у жінок із високим індексом маси тіла (IMT) частіше спостерігаються викидні $(10,7$ \% у жінок із нормальним IMT, 13,6 \% у жінок з IMT більше 30 [30]), рецидиви викиднів на ранніх термінах, погіршується імплантація плода [31] тощо. Вчені припускають, що ці негативні наслідки можуть бути пов'язані з фролікулярним навколишнім середовищем, яке відрізняється у жінок з надлишковою масою тіла, порівняно із жінками 3 нормальною масою: підвищення у фолікулярній рідині рівня інсуліну, лактату, тригліцеридів та С-реактивного білка, а також зменшення SHBG [32]. Негативний вплив ожиріння на фрертильність жінок може бути оборотним. Clark A. М. та співавт. (1998) вказують, що після схуднення в середньому на 10,2 кг у 90 \% жінок із ожирінням, які мали діагноз ановуляції, почалася овуляція [19, 33].

У жінок із недостатньою масою, які мають низьку частку жиру в організмі, спостерігаються дисфрункція яєчників та безпліддя: ризик овуляторного безпліддя зростає у жінок з ІМТ нижче 17 [19, 34]. Freizinger M. та ін. у своїх дослідженнях повідомляють, що у 20,7 \% безплідних жінок, які планують вагітність за допомогою внутрішньоматкової інсемінації, діагностовано розлад харчової поведінки. Вони припускають, що жінки з істо- рією харчових розладів перебувають у зоні ризику щодо виникнення безпліддя [35].

Куріння. Серед жінок репродуктивного віку 30 \% курці. Augood C. та ін. визначили, що жінки-курці мали значно вищий коефріцієнт безпліддя, порівняно з некурцями [36]. Це може бути зумовлено зниженням функції яєчників та їх виснаженням. Sharara F. I. та ін. наводять такі результати: частота зниження оваріального резерву була значно вищою у курців - 12,31 \% проти 4,83 \% [19]. Куріння призводить до порушення рівня гормонів у жінок, що теж впливає на їх фертильність:

- у жінок, які викурюють 10 і більше цигарок на день, рівень ФСГ у сечі збільшується на 30-35 \%;

- жінки, які викурюють 20 і більше цигарок на день, мають нижчий рівень прогестерону в лютеїновій сразі [37].

Такі порушення в роботі ендокринної функції можуть призводити до порушення менструальної фрункції та безпліддя. Хімічні речовини, які містяться в цигарковому димі, погіршують фрормування ооцитів і транспортування ембріонів у маткових трубах, що призводить до збільшення частоти позаматкової вагітності та безпліддя серед жінок-курців [38].

Алкоголь. Вплив алкоголю на репродуктивну систему жінки залежить від кількості та частоти споживання. Збільшення споживання алкоголю від одного разу на тиждень до 5 разів на день може мати різний ефрект: збільшується період до зачаття [39], зменшується ймовірність зачаття більш ніж на 50 \% [19], а також зменшується швидкість імплантації, виникають ановуляція, диссрункція лютеїнової фрази та розвиток аномальних бластоцист [40]. Механізм впливу алкоголю на фрертильність жінки вивчений погано, дослідники припускають, що алкоголь порушує гормональний баланс, викликає збільшення рівня естрогену, який знижує ФСГ і пригнічує фролікулогенез та овуляцію [40, 41],

Забруднення навколишнього середовища. На срертильність жінки негативно впливають біологічні (віруси), фрізичні (радіаційні) та токсичні (хімічні) фрактори навколишнього середовища [19]. Забруднення повітря діоксидами сірки та азоту, чадним газом, твердими частками може спричинювати передчасні пологи, викидні, мертвонародження, спонтанні аборти [42]. Часто причиною втрати плода були вади розвитку всередині його репродуктивної системи [19].

Хіміотерапія виснажує первинні фоллікули, при цьому ризик токсичності під час хіміотерапії збільшується з віком. Так само радіація уражає яєчники залежно від дози, типу та віку пацієнта [43].

Висновки. Аналіз літературних джерел показав, що на стан яєчників та оваріальний резерв негативно впливають різні фрактори: анамнез (генетична схильність, ускладнений пренатальний період, операції на яєчниках, ендометріоз, інсекції органів таза, соматична патологія), вік, стиль життя (індекс маси тіла, вживання алкоголю та кави, куріння), шкідливі фрактори навколишнього середовища (атмосорерозабруднюючі речовини, пестициди, радіоактивні агенти). 


\section{СПИСОК ЛІТЕРАТУРИ}

1. Колянчук Я. В. Проблема оцінки репродуктивної токсичності (гонадотоксичності) пестицидів / Я. В. Колянчук // Медична та клінічна хімія. - 2018. - Т. 20, № 2. - С. 123-130.

2. Padmanabhan V. Sheep models of polycystic ovary syndrome phenotype / V. Padmanabhan, A. Veiga-Lopez // Mol. Cell. Endocrinol. - 2013. - Vol. 373 (1-2). - P. 8-20.

3. Ковалишин О. А. Стан оваріального резерву в жінок, які мали порушення менструальної функції у пубертатному періоді / О. А. Ковалишин // Семейная медицина. - 2029. № 4 (89). - C. 92-96.

4. Макарчук О. М. Характеристика репродуктивного потенциала у женщин с нарушением становления менструальной фрункции в пубертате, методы профилактики и коррекции / О. М. Макарчук, В. Б. Дзьомбак // Репродуктивное здоровье. Восточная Европа. - 2017. - Т. 7, № 4. - С. 522-529.

5. Морфологічні та імуногістохімічні особливості ендометрія в період «вікна імплантації» у жінок з безпліддям на тлі хронічних запальних захворювань внутрішніх статевих органів / А. Є. Дубчак, Т. Д. Задорожна, О.В.Мілєвський, О. І. Довгань // Здоров'я жінки. - 2015. - № 6 (102). - С. 178-181.

6. Безнощенко Г. Б. Проблема оперированного органа в гинекологии / Г. Б. Безнощенко // Российский вестник акушера-гинеколога. - 2003. - № 2. - С. 28-33.

7. Mostaejeran F. Evaluation of antimullerian hormone levels before and after laparoscopic management of endometriosis / F. Mostaejeran, Z. Hamoush, S. Rouholamin // Adv. Biomed. Res. - 2015. - Vol. 4. - P. 182.

8. Давидов А. І. Оцінка оваріального резерву після ендохірургічних втручань на яєчниках з використанням високих енергій / А. І. Давидов, Р. Д. Мусаїв // Питання гінекології. 2011. - Т. 10, № 3. - С. 56-63.

9. Особливості оваріального резерву у жінок з безплідністю після органозберігаючих операцій на органах малого таза / А. Є. Дубчак, О. Д. Дубенко, О.В.Мілєвський, Н. М. Обейд // Здоров'я жінки. - 2017. - № 3 (119). - С. 46-49.

10. Боярский К. Ю. Роль антимюллерова гормона (АМГ) в норме и при различных гинекологических заболеваниях / К. Ю. Боярский, С. Н. Гайдуков, Е. А. Машкова // Журнал акушерства и женских болезней. - 2009. - № 58. - С. 74-83.

11. Assessment of ovarian function after cesarean hysterectomyat zagazig university hospitals / R. A. Ibrahim, A. A. Nouh, A. A. Elnemr, W. El-Nagar // Zagazig University Med. J. - 2020. DOI: 10.21608/zumj.2020.21993.1675.

12. Кулаков В. И. Оперативная гинекология - хирургические энергии : руководство / В. И. Кулаков, Л. В. Адамян, О. А. Мынбаев. - М. : Медицина : Антидор, 2000. - 861 с.

13. Role of tubal surgery in the era of assisted reproductive technology: a committee opinion / Practice Committee of the American Society for Reproductive Medicine // Fertil. Steril. 2015. - Vol. 103 (6). - P. e37-e43.

14. Іщак О. М. Вплив різних варіантів оперативного лікування апоплексії яєчника на стан оваріального резерву / О. М. Іщак // Здоровье женщины. - 2018. - № 4. - С. 75-77.

15. Follow up of women after laparoscopy versus laparotomy in emergency gynecological problems / E. M. Yaseen // Med. J. Tikrit University. - 2018. - Vol. 24 (1). - P. 109-127.

16. Szafarowska M. Ovarian aging \& infertility / M. Szafarowska, M. Jerzak // Ginekol. Pol. - 2013. - Vol. 84 (4). - P. 298-304.

17. Rasool S. Fertility with early reduction of ovarian reserve: the last straw that breaks the Camel's back / S. Rasool, D. Shah // Fertil. Res. Pract. - 2017. - Vol. 3. - P. 15.

18. Ovarian reserve assessment for infertility investigation / B. R. Carvalho, D. B. G. Sobrinho, A. D. D. Vieira [et al.] // ISRN Obstet. Gynecol. - 2012. - Vol. 2012. - P. 576385.
19. Lifestyle factors and reproductive health: taking control of your fertilit / R. Sharma, K. R. Biedenharn, J. M. Fedor, A. Agarwal // Reprod. Biol. Endocrinol. -2013. - Vol. 11. - P. 66.

20. Decline in human fertility rates with male age: a consequence of a decrease in male fecundity with aging? / R. Matorras, F. Matorras, A. Exposito [et al.] // Gynecol. Obstet. Invest. - 2011. - Vol. 71 (4). - P. 229-235.

21. Predicting aneuploidy in human oocytes: key factors which affect the meiotic process / L. Gianaroli, M. C. Magli, G. Cavallini [et al.] // Hum. Reprod. - 2010. - Vol. 25 (9). P. 2374-2386.

22. Miscarriage karyotype and its relationship with maternal body mass index, age, and mode of conception / B. Kroon, K. Harrison, N. Martin [et al.] // Fertil. Steril. - 2011. - Vol. 95 (5). - P. 1827-1829.

23. Stewart A. F. Fertility concerns for the aging male / A. F. Stewart, E. D. Kim // Urology. -2011. - Vol. 78 (3). - P. 496-499.

24. Kimberly L. Advanced reproductive age and fertility / L. Kimberly, A. Case // J. Obstet. Gynaecol. Can. - 2012. Vol. 33 (11). - P. 1165-1175.

25. Protein intake and ovulatory infertility / J. E. Chavarro, J. W. Rich-Edwards, B. A. Rosner, W. C. Willett // Am. J. Obstet. Gynecol. - 2008a. - Vol. 198 (2). - P. 210.

26. Dietary fatty acid intakes and the risk of ovulatory infertility / J. E. Chavarro, J. W. Rich-Edwards, B. A. Rosner, W. C. Willett // Am. J. Clin. Nutr. - 2007. - Vol. 85 (1). - P. 231-237.

27. Use of multivitamins, intake of $B$ vitamins, and risk of ovulatory infertility / J. E. Chavarro, J. W. Rich-Edwards, B. A. Rosner, W. C. Willett // Fertil. Steril. - 20086. - Vol. 89 (3). P. 668-676.

28. Risk factors for diminished ovarian reserve and the role of endometriosis / K. Lin, B. Samantha, M. D. Sammel, K. T. Barnhart // Fertil. Steril. - 2010. - Vol. 94 (4). - P. S63.

29. Monniaux D. Factors influencing establishment of the ovarian reserve and their effects on fertility / D. Monniaux // Anim. Reprod. - 2018. - Vol. 15 (Suppl. 1). - P. 635-647.

30. Boots C. Does obesity increase the risk of miscarriage in spontaneous conception: A systematic review / C. Boots, M. D. Stephenson // Semin. Reprod. Med. - 2011. - Vol. 29 (6). - P. 507-513.

31. Obesity and poor reproductive outcome: The potential role of the endometrium / J. Bellver, M. A. Melo, E. Bosch [et al.] // Fertil. Steril. - 2007. - Vol. 88 (2). - P. 446-451.

32. Obese women exhibit differences in ovarian metabolites, hormones, and gene expression compared with moderateweight women / R. L. Robker, L. K. Akison, B. D. Bennett [et al.] // J. Clin Endocrinol. Metab. - 2009. - Vol. 94 (5). - P. 1533-1540.

33. Weight loss in obese infertile women results in improvement in reproductive outcome for all forms of fertility treatment / A. M. Clark, B. Thornley, L. Tomlinson [et al.] // Hum. Reprod. - 1998. - Vol. 13 (6). - P. 1502-1505.

34. Han Z. Maternal underweight and the risk of preterm birth and low birth weight: A systematic review and meta-analyses / Z. Han, S. Mulla, J. Beyene // Int. J. Epidemiol. - 2011. Vol. 40 (1). - P. 65-101.

35. The prevalence of eating disorders in infertile women / M. Freizinger, D. L. Franko, M. Dacey [et al.] // Fertil. Steril. 2010. - Vol. 93 (1). - P. 72-78.

36. Augood C. Smoking and female infertility: A systematic review and meta-analysis / C. Augood, K. Duckitt, A. A. Templeton // Hum. Reprod. -1998. -Vol. 13 (6). -P. 1532-1539.

37. Cigarette smoking and effects on hormone function in premenopausal women / G. C. Windham, P. Mitchell, M. Anderson [et al.] // Environ. Health Perspect. - 2005. Vol. 113 (10). - P. 1285-1290. 
38. Talbot P. Smoking and reproduction: The oviduct as a target of cigarette smoke / P. Talbot, K. Riveles // Reprod. Biol. Endocrinol. - 2005. - Vol. 3. - P. 52.

39. The influence of maternal and paternal factors on time to pregnancy-a dutch population-based birth-cohort study: the GECKO drenthe study / M. A. Mutsaerts, H. Groen, H. G. Huiting [et al.] // Hum. Reprod. - 2012. - Vol. 27 (2). - P. 583-593.

40. Gill J. The effects of moderate alcohol consumption on female hormone levels and reproductive function / J. Gill // Alcohol Alcohol. - 2000. -Vol. 35 (5). - P. 417-423.

\section{REFERENCES}

1. Kolianchuk, Y.V. (2018). Problema otsinky reproduktyvnoi toksychnosti (honadotoksychnosti) pestytsydiv [The problem of assessment of reproductive toxicity (gonadotoxic) pesticides] Medychna ta klinichna khimiia - Medical and Clinical Chemistry, 20 (2), 123-130. DOI: 10.11603/mcch.2410-681X.2018. v0.i2.9136 [in Ukrainian].

2. Padmanabhan, V., \& Veiga-Lopez, A. (2013). Sheep models of polycystic ovary syndrome phenotype. Mol. Cell. Endocrinol., 373, 8-20. DOI: 10.1016/j.mce.2012.10.005.

3. Kovalishin, O.A. (2020). Stan ovarialnoho rezervu v zhinok yaki maly porushennia menstrualnoi funktsii u pubertatnomu periodi [Ovarian reserve condition in women with menstrual dysfunction in the puberty]. Semeynaya meditsina - Family Medicine, 4 (89), 92-96 [in Russian]

4. Makarchuk, O.M., \& Dz'ombak, V.B. (2017). Kharakteristika reproduktivnogo potentsiala $u$ zhenshchin $s$ narusheniem stanovleniya menstrualnoy funktsii $v$ pubertate, metody profilaktiki i korrektsii [Characteristics of the reproductive potential in women with impaired formation of menstrual function in puberty, methods of prevention and correction]. Reproduktivnoe zdorove. Vostochnaya Evropa-Reprod. Health. East. Eur., 7 (4), 522-529 [in Russian].

5. Dubchak, A.Ye., Zadorozhna, T.D., Milievskyi, O.V., \& Dovhan, O.I. (2015). Morfolohichni ta imunohistokhimichni osoblyvosti endometriia $v$ period vikna implantatsii u zhinok z bezpliddiam na tli khronichnykh zapalnykh zakhvoriuvan vnutrishnikh statevykh orhaniv [Morphological and immunohistochemical features of the endometrium during the "implantation window" in women with infertility on the background of chronic inflammatory disease of the internal genital organs]. Zdorovye zhenshchyny - Women's Health, 6 (102), 178-181 [in Ukrainian]

6. Beznoshchenko, H.B (2003). Problema operyrovannoho orhana $\mathrm{v}$ ginekologii [The problem of the operated organ in gynecology]. Rossyiskyi vestnyk akushera-ginekologa - Russian Bulletin of Obstetrician-Gynecologist, 2, 28-33 [in Russian].

7. Mostaejeran, F., Hamoush, Z., \& Rouholamin, S. (2015). Evaluation of antimullerian hormone elevels before and after laparoscopic management of endometriosis. Adv. Biomed. Res, 31 (4), 182. DOI: 10.4103/2277-9175.164006.

8. Davydov, A.I., \& Musaiv, R.D. (2011). Otsinka ovarialnoho rezervu pislia endokhirurhichnykh vtruchan na yaiechnykakh z vykorystanniam vysokykh [Asseement of ovarian reserve after endosurgery on the ovaries using high energies]. Pytannia hinekolohii - Issue of Gynecology, 10 (3), 56-63 [in Russian].

9. Dubchak, A.Ye., Dubenko, O.D., Milevskyi, O.V., \& Obeid, N.M. (2017). Osoblyvosti ovarialnoho rezervu u zhinok z bezplidistiu pislia orhanozberihaiuchykh operatsii na orhanakh maloho taza [Infertility after organ-spering operations on the pelvic organs]. Zdorovia zhinky - Women's Health, 3, 46-49. DOI: 10.15574/HW.2017.119.46.

10. Boiarskyi, K.lu. Gaydukov, S.N., \& Mashkova E.A. (2009). Rol antymiullerovoho hormonu (AMH) v normi i pry
41. Eggert J. Effects of alcohol consumption on female fertility during an 18-year period / J. Eggert, H. Theobald, P. Engfeldt // Fertil. Steril. - 2004. - Vol. 81 (2). - P. 379-383.

42. Chalupka $S$. The impact of environmental and occupational exposures on reproductive health / S. Chalupka, A. N. Chalupka // JOGNN. - 2010. - Vol. 39 (1). - P. 84-102.

43. Beerendonk C. C. Present and future options for the preservation of fertility in female adolescents with cancer / C. C. Beerendonk, D. D. Braat // Endocr. Dev. - 2005. Vol. 8. - P. 166-175.

riznykh hinekolohichnykh zakhvoriuvanniakh [The role of antiMullerian hormone (AMH) in health and in various gynecological diseases]. Zhurnal akusherstva i zhinochykh khvorob-J. Obstet. Women's Dis., 58, 74-83 [in Ukrainian].

11. Ibrahim, R.A., Nouh, A.A., Elnemr, A.A., \& El-Nagar, W.M. (2020). Assessment of ovarian function after cesarean hysterectomy at Zagazig University Hospitals. Zagazig University Med. J., DOI: 10.21608/zumj.2020.21993.1675.

12. Kulakov, V.I., Adamian, L.V., \& Mynbaiev, O.A. (2000). Operatyvna hinekolohiia - khirurhichni enerhii: rukovodstvo [Operative gynecology - surgical energies: guide]. Moscow: Meditsina [in Russian].

13. Practice Committee of the American Society for Reproductive Medicine (2015). Role of tubal surgery in the era of assisted reproductive technology: a committee opinion. Fertil. Steril., 103 (6), e37-e43. DOI: 10.1016/j.fertnstert.2015.03.032.

14. Ishchak, O.M. (2018). Vplyv riznykh variantiv operatyvnoho likuvannia apopleksii yaiechnyka na stan ovarialnoho rezervu [The influence of different options for surgical treatment of ovarian apoplexy on the state of the ovarian reserve]. Zdorovye zhenshchiny - Women's Health, 4, 75-77 [in Russian].

15. Yaseen, E.M. (2018). Follow up of women after laparoscopy versus laparotomy in emergency gynecological problems. Med. J. Tikrit University, 24 (1), 109-127. DOI: 10.25130/ mjotu.24.01.11.

16. Szafarowska, M., \& Jerzak, M. (2013). Ovarian aging \& infertility. Ginekologia Polska, 84 (4), 298-304. DOI: 10.17772/ gp/1580.

17. Rasool, S., \& Shah, D. (2017). Fertility with early reduction of ovarian reserve: the last straw that breaks the Camel's back. Fertil. Res. Pract., 3, 15. DOI: 10.1186/s40738017-0041-1.

18. Carvalho, B.R., Sobrinho, D.B.G., Vieira, A.D.D., Resende, M.P.S., Barbosa, A.C.P., Silva, A.A., \& Nakagava, H.M. (2012). Ovarian reserve assessment for infertility investigation. Obstet. Gynecol., 2012, 576385. DOI: 10.5402/2012/576385.

19. Sharma, R., Biedenharn, K.R, Fedor, J.M., \& Agarwal, A. (2013). Lifestyle factors and reproductive health: taking control of your fertility. Reprod. Biol. Endocrinol., 11, 66. DOI: 10.1186/1477-7827-11-66.

20. Matorras, R., Matorras, F., Exposito, A., Martinez, L., \& Crisol, L. (2011). Decline in human fertility rates with male age: a consequence of a decrease in male fecundity with aging? Gynecol. Obstet. Invest., 71, 229-235. DOI: 10.1159/000319236.

21. Gianaroli, L., Magli, M.C., Cavallini, G., Crippa, A., Capoti, A., Resta, S., Robles, F., \& Ferraretti, A.P. (2010). Predicting aneuploidy in human oocytes: key factors which affect the meiotic process. Hum. Reprod., 25, 2374-2386. DOI: 10.1093/humrep/deq123.

22. Kroon, B., Harrison, K., Martin, N., Wong, B., \& Yazdani, A. (2011). Miscarriage karyotype and its relationship with maternal 
body mass index, age, and mode of conception. Fertil. Steril., 95, 1827-1829. DOI: 10.1016/j.fertnstert.2010.11.065.

23. Stewart, A.F., \& Kim, E.D. (2011). Fertility concerns for the aging male. Urology, 78, 496-499. DOI: 10.1016/j. urology.2011.06.010.

24. Kimberly, L., \& Case, A. (2011). Advanced reproductive age and fertility. Int. J. Gynecol. Obstet., 33 (11), 1165-1175. DOI: 10.1016/S1701-2163(16)35087-3.

25. Chavarro, J.E., Rich-Edwards, J.W., Rosner, B.A., \& Willett, W.C. (2008a). Protein intake and ovulatory infertility. Am. J. Obstet. Gynecol., 198 (2), 210. DOI: 10.1016/j. ajog.2007.06.057.

26. Chavarro, J.E., Rich-Edwards, J.W., Rosner, B.A., \& Willett, W.C. (2007a). Dietary fatty acid intakes and the risk of ovulatory infertility. Am. J. Clin. Nutr., 8, 231-237. DOI: 10.1093/ ajcn/85.1.231.

27. Chavarro, J.E., Rich-Edwards, J.W., Rosner, B.A., \& Willett, W.C. (2008b). Use of multivitamins, intake of B vitamins, and risk of ovulatory infertility. Fertil. Steril., 89 (3), 668-676. DOI: 10.1016/j.fertnstert.2007.03.089.

28. Lin, K., Samantha, B., Sammel, M.D., \& Barnhart, K.T. (2010). Risk factors for diminished ovarian reserve and the role of endometriosis. Fertil. Steril., 94 (4), S63. DOI: 10.1016/j. fertnstert.2010.07.247.

29. Monniaux, D. (2018). Factors influencing establishment of the ovarian reserve and their effects on fertility. Anim. Reprod., 15 (Suppl. 1), 635-647. DOI: 10.21451/1984-3143-AR20180011.

30. Boots, C., \& Stephenson, M.D. (2011). Does obesity increase the risk of miscarriage in spontaneous conception: A systematic review. Semin. Reprod. Med., 29 (6), 507-513. DOI: 10.1055/s-0031-1293204.

31. Bellver, J., Melo, M.A., Bosch, E., Serra, V., Remohi, J., \& Pellicer, A. (2007). Obesity and poor reproductive outcome: The potential role of the endometrium. Fertil. Steril., 88 (2), 446-451. DOI: 10.1016/j.fertnstert.2006.11.162.

32. Robker, R.L., Akison, L.K., Bennett, B.D., Thrupp, P.N., Chura, L.R., Russell, D.L., ..., \& Norman, R.J. (2009). Obese women exhibit differences in ovarian metabolites, hormones, and gene expression compared with moderateweight women. J. Clin. Endocrinol. Metab., 94 (5), 1533-1540. DOI: $10.1210 / j c .2008-2648$.

33. Clark, A.M., Thornley, B., Tomlinson, L., Galletley, C., \& Norman, R.J. (1998). Weight loss in obese infertile women results in improvement in reproductive outcome for all forms of fertility treatment. Hum. Reprod., 13 (6), 1502-1505. DOI: 10.1093/humrep/13.6.1502.

34. Han, Z., Mulla, S., Beyene, J., Liao, G., \& McDonald, S.D. (2011). Maternal underweight and the risk of preterm birth and low birth weight: A systematic review and meta-analyses. Int. J. Epidemiol., 40 (1), 65-101. DOI: 10.1093/ije/dyq195.

35. Freizinger, M., Franko, D.L., Dacey, M., Okun, B., \& Domar, A.D. (2010). The prevalence of eating disorders in infertile women. Fertil. Steril., 93 (1), 72-78. DOI: 10.1016/j. fertnstert.2008.09.055.

36. Augood, C., Duckitt, K., \& Templeton, A.A. (1998). Smoking and female infertility: A systematic review and metaanalysis. Hum. Reprod., 13 (6), 1532-1539. DOI: 10.1093/ humrep/13.6.1532.

37. Windham, G.C., Mitchell, P., Anderson, M., \& Lasley, B.L. (2005). Cigarette smoking and effects on hormone function in premenopausal women. Environ. Health Perspect., 113 (10), 1285-1290. DOI: 10.1289/ehp.7899.

38. Talbot, P., \& Riveles, K. (2005). Smoking and reproduction: The oviduct as a target of cigarette smoke. Reprod. Biol. Endocrinol., 3, 52. DOI: 10.1186/1477-7827-3-52.

39. Mutsaerts, M.A., Groen, H., Huiting, H.G., Kuchenbecker, W.K., Sauer, P.J., Land, J.A., ..., \& Hoek, A. (2012). The influence of maternal and paternal factors on time to pregnancy a dutch population-based birth-cohort study: the GECKO drenthe study. Hum. Reprod., 27 (2), 583-593. DOI: 10.1093/humrep/der429.

40. Gill, J. (2000). The effects of moderate alcohol consumption on female hormone levels and reproductive function. Alcohol Alcohol., 35 (5), 417-423. DOI: 10.1093/ alcalc/35.5.417.

41. Eggert, J., Theobald, H., \& Engfeldt, P. (2004). Effects of alcohol consumption on female fertility during an 18year period. Fertil. Steril., 81 (2), 379-383. DOI: 10.1016/j. fertnstert.2003.06.018.

42. Chalupka, S., \& Chalupka, A.N. (2010). The impact of environmental and occupational exposures on reproductive health. J. Obstet. Gynecol. Neonatal Nurs., 39 (1), 84-102. DOI: $10.1111 /$ j.1552-6909.2009.01091.x.

43. Beerendonk, C.C., \& Braat, D.D. (2005). Present and future options for the preservation of fertility in female adolescents with cancer. Endocr. Develop., 8, 166-175. DOI: $10.1159 / 000084101$.

Отримано 30.09.20

Прийнято до друку 29.10 .20

Електронна адреса для листування: denefil@tdmu.edu.ua 